\title{
Teacher Professional Development Needs in Using Digital Technology for Quality of Education
}

\author{
Maimun', Mohammad Viktor Farid Hakim² \\ DOI: 10.35445/alishlah.v13i2. 642
}

\begin{tabular}{l}
\hline Article Info \\
\hline Keywords: \\
Digital Technology; \\
Teacher Professional; \\
Quality Education
\end{tabular}

Kata kunci:

Teknologi Digital;

Guru Profesional;

Kualitas Pendidikan

\begin{abstract}
The research aims to obtain the professional development model needs of teachers in mastering digital technology to improve the quality of education. Technology development in education has forced all parties to integrate various educational activities according to current conditions. The research method used mixed research involving qualitative and quantitative data analysis. Data were collected through a survey which was completed with observation and interviews. Analysis of qualitative data is in the form of narrative through data reduction, data presentation, and concluding stages. In contrast, quantitative data is the result of digital technology needs presented in percentages. The analysis results show that digital technology is still not fully used in teaching and learning activities. This also impacts teachers' understanding of the technology application model in schools and students' achievement.
\end{abstract}

\begin{abstract}
Abstrak
Penelitian bertujuan untuk mendapatkan kebutuhan model pengembangan professional guru dalam penguasaan teknologi digital untuk meningkatkan kualitas pendidikan. Perkembangan teknologi di dunia Pendidikan telah memaksa semua pihak untuk memadukan berbagai aktivitas pendidikan dengan kemajuan teknologi sesuai kondisi saat ini. Metode penelitian menggunakan penelitian campuran yang melibatkan analisis data kualitatif dan kuantitatif. Data dikumpulkan melalui survei yang dilengkapi dengan kegiatan observasi dan wawancara. Analisis data kualitatif dalam bentuk narasi melalui tahap reduksi data, penyajian data dan penarikan simpulan, sedangkan data kuantitatif merupakan hasil kebutuhan teknologi digital yang disajikan melalui prosentase. Hasil analisis menunjukkan bahwa teknologi digital masih belum digunakan secara utuh dalam kegiatan pengajaran dan pembelajaran. Hal ini berdampak pula pada pemahaman guru terhadap model penerapan teknologi di sekolah dan juga hasil belajar siswa.
\end{abstract}

\footnotetext{
${ }^{1}$ Universitas Islam Negeri Mataram, Indonesia Email: mohammadviktorfaridh@gmail.com

${ }_{2}$ Universitas Islam Negeri Mataram, Indonesia

Email: mohammadviktorfaridh@gmail.com
} 


\section{INTRODUCTION}

The development and global life that continues to grow requires everyone to have qualities that can compete and face the world's challenges. To create a quality nation, Indonesia must provide quality education. Therefore, teachers and lecturers have very strategic functions, roles, and positions. Article 39 Paragraph (2) of Law Number 20 of 2003 concerning the National Education System states that educators are professionals. The position of teachers and lecturers as professionals has a vision of realizing the implementation of learning by the principles of professionalism to fulfil equal rights for every citizen in obtaining a quality education.

Therefore, qualifications for professional teachers must have four pedagogical competencies, personality competencies, social competencies, and professional competencies. Professional competence is required to have qualified knowledge and be able to keep up with changes in science and technological developments. Changes in science and technology have significantly impacted teacher professionalism in carrying out teaching and learning. The digital era has been used to manage educational institutions for both teaching and administrative activities. Digital transformation has influenced pedagogy (Zain, 2021; Budaghyan, 2015).

Educational institutions have directed and required teachers to use digital technology to teach (Nykvist \& Mukherjee, 2016). One way that has been implemented is that e-portfolios contribute to professional development. There are many ways that teachers can do in implementing their professional work in teaching and learning activities. So, the demands of the digital era lead to the concept of a teacher's professional identity context to integrate technology in teaching. Thus, every school must support the development of teachers' professional identity to become qualified educators (Avidov-Ungar \& Forkosh-Baruch, 2018). In this case, the way teachers conduct teaching is at the root of their professional identity (Richter et al., 2021; Zeng, 2020). Teacher professional learning is a complex process that requires teachers' cognitive and emotional involvement individually and collectively (Avalos, 2011). Therefore, teachers must continue to participate in continuous professional development (De Vries et al., 2013) because 21st-century teacher professionals with classroom management are closely intertwined to realize creative and innovative skills, communication, media awareness, computer literacy and information technology (Ninlawan, 2015). Thus, teachers and students need meaningful involvement to support and take advantage of each other to produce professionalism, empowerment, and substantial self-improvement of teachers (Tsybulsky \& Muchnik-Rozanov, 2019). Thus, the gap of study is different from previous research is related to the professionalism of teachers for mastering digital technology as an online learning medium during the COVID-19 pandemic.

Previous research illustrates that professional teachers are related to the way they teach in the classroom. In this case, the teacher has good classroom management skills to manage teaching and learning. Professional development usually is related to learning activities and the development of learning communities. There is a growing interest in developing schools as learning organizations and ways for teachers to share their expertise and experiences systematically. However, this research focuses on the professional development of teachers in mastering digital technology related to improving the quality of education.

This study examines the competence of mastering technology which is growing very fast and has influenced educational activities. This is important because, currently, during the Covid-19 pandemic, technological developments that continue to require the learning process to be carried out using digital technology tools as media. The COVID-19 pandemic period requires learning activities to be carried out online. Teachers must use digital tools as a medium for delivering material, such as zoom, website learning, google meet, etc. The government has also provided many technological applications as online learning media. Conditions like this require mastery of digital tools to facilitate the online learning process. The results of observations in preliminary research concluded that teacher 
professionalism is required in the teaching and learning process to use digital tools so that online learning activities during the COVID-19 pandemic can achieve the goals that have been set. Therefore, this research aims to obtain the professional development of teachers in mastering digital technology for the quality of education. This research is also expected to provide teachers with the appropriate digital technology to teach in the classroom.

\section{METHODS}

This study used the descriptive qualitative method (Creswell \& Creswell, 2018), which examines the phenomena in the field according to the context. Research data was collected to know the teacher's professionalism needs in implementing digital technology tools for teaching and learning. In this case, the research explores the experience and ability of teachers to master the technology tools applied in academic life in schools, especially in the learning process activities. So, the data collection technique used interviews and observations. Data were analyzed through some steps, namely data reduction, data presentation, data analysis, and concluding.

This study was conducted at the Integrated Elementary School Mataram. The data are based on a study of primary school teachers $(\mathrm{N}=10)$. This study uses "a variety of interrelated interpretive practices" (Denzin \& Lincoln, 2005) to identify teacher use of mobile devices and technology. Meanwhile, semi-structured interviews and questionnaires were also addressed to all teachers and principals at the Integrated Elementary School Mataram.

\section{FINDINGS AND DISCUSSION}

This data is taken from the survey result to know teachers' professionalism in the digital technology aspect. Professional development includes support for teachers or staff as they apply technology to their evolving educational delivery practices, from lesson planning and curriculum integration to record-keeping and administration functions. The results of the survey are presented in the form of percentage graphs;

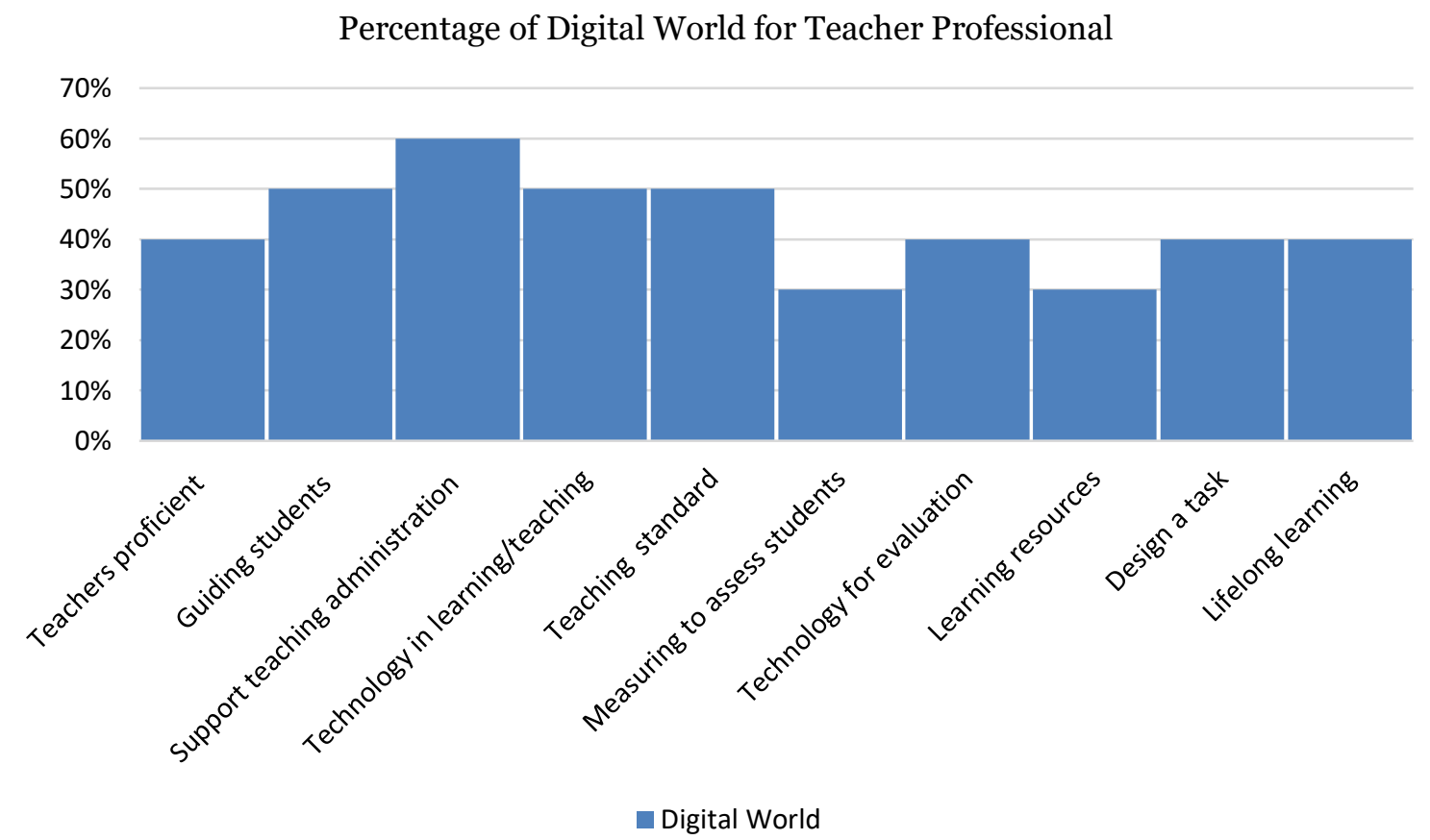

Graph 1. Teacher Professional Development in Using Digital Technology

Graph 1 illustrates that the professionalism of teachers in mastering technology is still low. This can be seen from the ten indicators on the chart with a low percentage. Teachers are still not proficient in mastering technology. It affects the desired performance of teachers to be technology literate. The interview results also show that teachers expect school support to improve their skills 
in mastering technology, such as carrying out various training activities. The educational role for teachers supports their professional work (Instefjord \& Munthe, 2017). In this case, teachers realize the importance of various competencies to support their work (Carpenter et al., 2020). In this case, the teachers understand the perspective of mastering technology personally and professionally (Rubach \& Lazarides, 2021).

Their perspective can guide students in using technology in the classroom, as illustrated in the second indicator with a percentage of $50 \%$. In this case, the teacher has a great desire to master technology, which can impact the application of students' technological literacy standards. Also, teachers can be assisted in integrating technology in curriculum design and implementing technology for teaching administration purposes. From the interviews with teachers, it was emphasized that a well-organized administration through the application of technology could help them analyze the needs of teaching and learning activities, such as the provision of materials, syllabus, curriculum, value administration system, and so on. However, the results of document observations have shown that the school administration section has used blogs to publish the school's existence so that the public can easily access it.

The fourth indicator shows that teachers want to integrate technology in learning and teaching. They still rarely use technology devices in class. Especially in the Covid-19 pandemic, which requires teaching and learning activities to be carried out at home, of course, requires the use of digital applications to make learning activities easier for students. However, this condition is also inversely proportional to the situation of students and the readiness of teachers to use digital technology. In contrast, learning activities that involve digital technology are related to student learning outcomes (Sailer et al., 2021). So, technology should be included in the standard of teaching needs, as described in the fifth indicator. Teachers have tried to apply technology tools in teaching activities even though learning activities have not significantly impacted student learning outcomes. Teachers can build classes into constructivist activities (Alt, 2018). Students can build basic and critical skills to help the process of communication and interaction in learning.

Thus, teachers are not proficient in applying technology for teaching and learning activities. It can be seen from the learning outcomes assessment and instructional evaluation activities manually. From the survey results, it can be seen that the sixth and seventh indicators have low percentage levels. In addition, teachers still have difficulty using digital technology as a learning resource. Finally, the provision of material is not authentic and is limited to student worksheets. The material is presented without following the context of the student's learning experience. Teachers need activities designed by schools to improve professional competence in mastering technology that can be used to explore learning resources, design learning assignments, or learning media. Moreover, learning activities are also a lifelong process. This means that digital technology can be a source for students to continue learning outside of school. Moreover, technological advances have made it easier for everyone to access information in the world.

\section{CONCLUSION}

The results of the study concluded that teachers need professional development that is integrated with digital technology. Various teaching and learning activities that are integrated with technology impact student learning outcomes and assumptions about lifelong learning. Teachers understand that schools must promote the role of digital technology in education through various activities to find out about various application models that can be used for learning activities in the classroom. In addition, mastery of digital technology influences the level of relevant knowledge and skills today. Students can also get higher quality learning outcomes.

The implications of the research results can be seen from the desire and enthusiasm of the teachers about digital technology information that can be applied in the classroom. In addition, it also helps teachers plan various teaching and learning activities to be better and more organized. 
However, this research is still limited to analyzing the needs of teachers for digital technology to improve their professional abilities. Thus, researchers can still identify applications of digital technology that can suit current needs for primary school student learning activities. In addition, research can also be related to various activities to increase mastery of digital technology according to the needs of teachers.

\section{REFERENCES}

Alt, D. (2018). Science teachers' conceptions of teaching and learning, ICT efficacy, ICT professional development and ICT practices enacted in their classrooms. Teaching and Teacher Education, 73, 141-150. https://doi.org/10.1016/j.tate.2018.03.020

Avalos, B. (2011). Teacher professional development in Teaching and Teacher Education over ten years. In Teaching and Teacher Education (Vol. 27, Issue 1, pp. 10-20). Pergamon. https://doi.org/10.1016/j.tate.2010.08.007

Avidov-Ungar, O., \& Forkosh-Baruch, A. (2018). Professional identity of teacher educators in the digital era in light of demands of pedagogical innovation. Teaching and Teacher Education, 73, 183-191. https://doi.org/10.1016/j.tate.2018.03.017

Budaghyan, S. (2015). Technology Teacher Training in a Remote Region of Armenia. Procedia Social and Behavioral Sciences, 197, 197-200. https://doi.org/10.1016/j.sbspro.2015.07.123

Carpenter, J. P., Rosenberg, J. M., Dousay, T. A., Romero-Hall, E., Trust, T., Kessler, A., Phillips, M., Morrison, S. A., Fischer, C., \& Krutka, D. G. (2020). What should teacher educators know about technology? Perspectives and self-assessments. Teaching and Teacher Education, 95, 103124. https://doi.org/10.1016/j.tate.2020.103124

Creswell, J. W., \& Creswell, J. D. (2018). Research Design: Qualitative, Quantitative, and Mixed Methods Approaches Fifth Edition. SAGE Publications Inc.

De Vries, S., Jansen, E. P. W. A., \& van de Grift, W. J. C. M. (2013). Profiling teachers' continuing professional development and the relation with their beliefs about learning and teaching. Teaching and Teacher Education, 33, 78-89. https://doi.org/10.1016/j.tate.2013.02.006

Denzin, N. K., \& Lincoln, Y. S. (2005). Introduction: The discipline and practice of qualitative research. In N.K. Denzin \& Y. S. Lincoln (Eds.), The Sage handbook of qualitative research (2nd ed.). SAGE.

Instefjord, E. J., \& Munthe, E. (2017). Educating digitally competent teachers: A study of integration of professional digital competence in teacher education. Teaching and Teacher Education, 67, 37-45. https://doi.org/10.1016/j.tate.2017.05.016

Ninlawan, G. (2015). Factors Which Affect Teachers' Professional Development in Teaching Innovation and Educational Technology in the 21st Century under the Bureau of Special Education, Office of the Basic Education Commission. Procedia - Social and Behavioral Sciences, 197, 1732-1735. https://doi.org/10.1016/j.sbspro.2015.07.228

Nykvist, S., \& Mukherjee, M. (2016). Who am I? Developing Pre-service Teacher Identity in a Digital World. Procedia - Social and Behavioral Sciences, 217, 851-857. https://doi.org/10.1016/j.sbspro.2016.02.012

Richter, E., Brunner, M., \& Richter, D. (2021). Teacher educators' task perception and its relationship to professional identity and teaching practice. Teaching and Teacher Education, 101, 103303. https://doi.org/10.1016/j.tate.2021.103303

Rubach, C., \& Lazarides, R. (2021). Addressing 21st-century digital skills in schools - Development and validation of an instrument to measure teachers' basic ICT competence beliefs. Computers in Human Behavior, 118, 106636. https://doi.org/10.1016/j.chb.2020.106636

Sailer, M., Schultz-Pernice, F., \& Fischer, F. (2021). Contextual facilitators for learning activities involving technology in higher education: The $\mathrm{Cb}$-model. Computers in Human Behavior, 121, 106794. https://doi.org/10.1016/j.chb.2021.106794

Tsybulsky, D., \& Muchnik-Rozanov, Y. (2019). The development of student-teachers' professional 
identity while team-teaching science classes using a project-based learning approach: A multilevel analysis. Teaching and Teacher Education, 79, 48-59. https://doi.org/10.1016/j.tate.2018.12.006

Zain, S. (2021). Digital transformation trends in education. In Future Directions in Digital Information (pp. 223-234). Elsevier. https://doi.org/10.1016/b978-0-12-822144-0.00036-7

Zeng, L. M. (2020). Peer review of teaching in higher education: A systematic review of its impact on the professional development of university teachers from the teaching expertise perspective. In Educational Research Review (Vol. 31, p. 100333). Elsevier Ltd. https://doi.org/10.1016/j.edurev.2020.100333 